Gut, 1980, 21, 413-417

\title{
Functional changes in acid secretion produced by duodenogastric reflux
}

\author{
W E G THOMAS* \\ From the Department of Applied Physiology and Surgical Sciences, Royal College of Surgeons of England, \\ and Department of Surgery, Addenbrookes Hospital, Cambridge
}

SUMMARY The effects of duodenal reflux on gastric secretion have been examined in dogs. Acid secretion during pentagastrin stimulation increased by $68 \%$ in animals with chronic diversion of duodenal contents into the stomach. This increased acid secretion did not occur when bile alone was diverted into the stomach and could be abolished by vagotomy. The hypersecretion observed with pentagastrin did not occur when histamine was the stimulus, which suggests that it was not due solely to a trophic effect on parietal cells.

Much attention has been focused on the possible role that reflux of duodenal contents into the stomach plays in the pathogenesis of peptic ulceration. Increased duodenal reflux has been demonstrated in a wide variety of conditions, including gastric and duodenal ulceration, ${ }^{1-3}$ and the morphological changes produced in the gastric mucosa have been examined. ${ }^{5}$ However, there is a marked absence of information about the functional effects of such reflux on gastric secretion, and the following experiments were performed in dogs to study these effects.

\section{Methods}

Adult litter-mate beagles were used to achieve uniformity of weight, size, and temperament. They were randomised into four groups, each of five animals: (1) a control group; (2) a group with duodenal reflux, which was produced by dividing the duodenum distal to the entry of the common bile duct and pancreatic ducts, and anastomosis of the duodenum to the upper lesser curve (Fig. 1, left), intestinal continuity was then restored by a posterior gastroduodenostomy; (3) a group with duodenal reflux as above but with the addition of truncal vagotomy; (4) a group with bile diversion alone, achieved by cholecystogastrostomy and ligation of the common bile duct (Fig. 1, right). All the dogs had a Gregory gastrostomy cannula.

At least one month was allowed after surgery before any secretion tests were undertaken, and

* Present address: Department of Surgery, Bristol Royal Infirmary, Bristol.

Received for publication 25 October 1979 throughout the trial dogs were kept in the same environment and fed on a standard diet. Before any test, it was ensured that the animal was in good health, and all tests were performed with the dog fully conscious, and not sedated.

Each dog was fasted for at least 18 hours before any experiment, and at least 36 hours was allowed to elapse between consecutive tests. Animals were trained to stand still in the restraining apparatus for periods up to eight hours, which they all tolerated extremely well.

At the beginning of each experiment, basal secretion was collected by gravity from the gastrostomy cannula for one hour; the volume and acid content were determined. Intravenous infusions in a solution of $0.9 \%$ sodium chloride were given with a Multispeed Precidor Infusion Pump.

Acid secretion was then studied by constructing dose-response curves to an intravenous infusion of pentagastrin with dose rates of $0 \cdot 5,1 \cdot 0,2 \cdot 0,4 \cdot 0$, and $8.0 \mu \mathrm{g} \mathrm{kg}^{-1} \mathrm{~h}^{-1}$. Each dose was administered for one hour to allow a stable level of acid response to be achieved. Acid output (mmol) was calculated for each 15 minute period throughout the experiment by noting the volumes and titrating the samples against $0 \cdot 1 \mathrm{MNaOH}$. Values in the Table are for the second half-hour at each dose rate. Two further tests on each dog were subsequently performed using prolonged infusions at a submaximal dose rate of $1.0 \mu \mathrm{g} \mathrm{kg}^{-1} \mathrm{~h}^{-1}$ and at a maximal dose rate of $8.0 \mu \mathrm{g} \mathrm{kg}^{-1} \mathrm{~h}^{-1}$ to ensure that the responses seen in the dose response curves were reliable.

Similar experiments were performed using histamine acid phosphate with dose rates of $10,20,40$, 80 , and $160 \mu \mathrm{g} \mathrm{kg}^{-1} \mathrm{~h}^{-1}$ and separate tests with pro- 

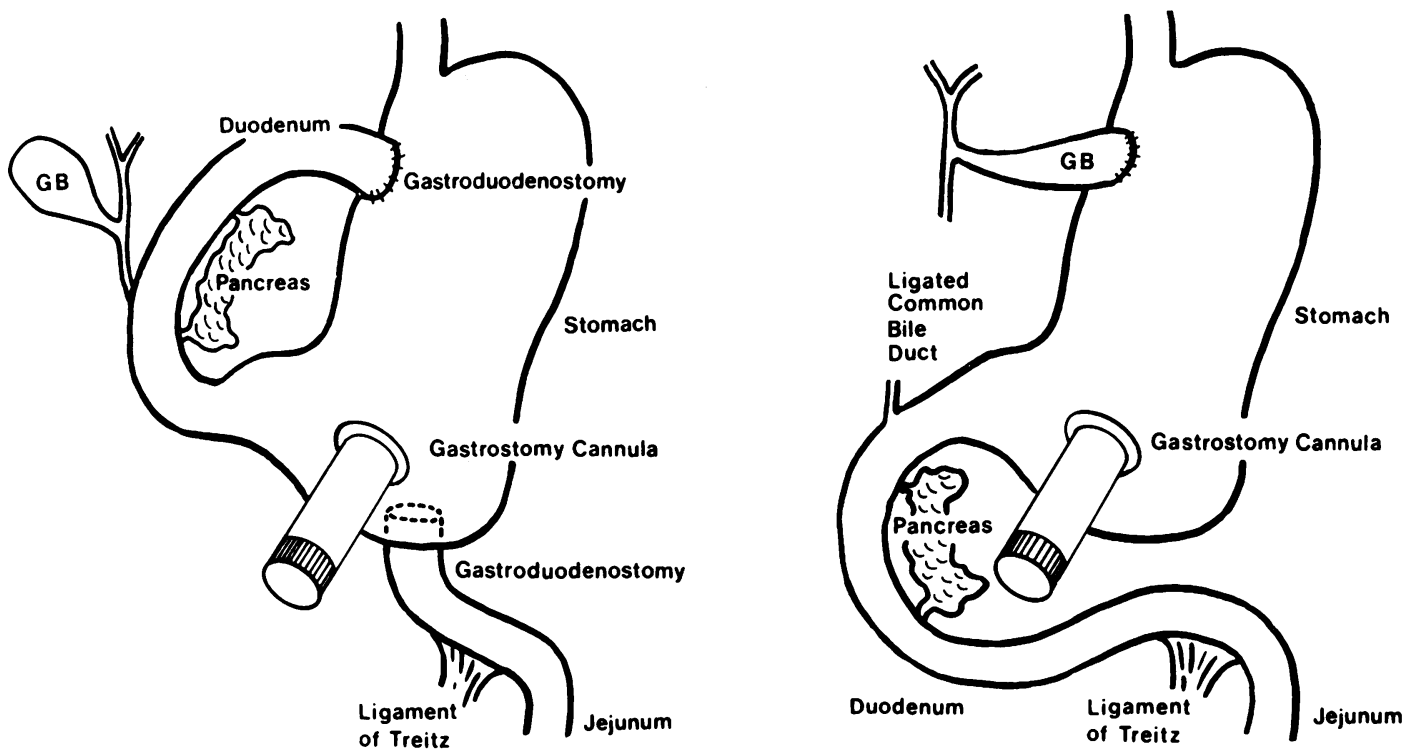

Fig. 1 (Left) The duodenal reflux preparation. (Right) The bile diversion preparation.

Table Maximal acid output $(\mathrm{m} \mathrm{mol} / 30 \mathrm{~min})$

\begin{tabular}{|c|c|c|c|c|c|c|c|c|}
\hline \multirow[b]{3}{*}{ Group } & \multicolumn{4}{|c|}{ Pentagastrin $8 \mu \mathrm{g} \mathrm{kg}^{-1} h^{-1}$} & \multicolumn{4}{|c|}{ Histamine $80 \mu \mathrm{g}^{-1} \mathrm{~h}^{-1}$} \\
\hline & \multicolumn{2}{|c|}{ Dose response curve } & \multicolumn{2}{|c|}{ Single tests } & \multicolumn{2}{|c|}{ Dose response curve } & \multicolumn{2}{|c|}{ Single tests } \\
\hline & Median & Range & Median & Range & Median & Range & Median & Range \\
\hline $\begin{array}{l}\text { Control } \\
\text { Duodenal reflux } \\
\text { Duodenal reflux with vagotomy } \\
\text { Bile diversion }\end{array}$ & $\begin{array}{r}9 \cdot 1 \\
15 \cdot 3 \\
4 \cdot 0 \\
6 \cdot 6\end{array}$ & $\begin{array}{r}8 \cdot 1-10 \cdot 0 \\
13 \cdot 1-23 \cdot 9 \\
2 \cdot 0-5 \cdot 2 \\
5 \cdot 1-9 \cdot 9\end{array}$ & $\begin{array}{c}9 \cdot 45 \\
14 \cdot 95 \\
3 \cdot 5 \\
6.0\end{array}$ & $\begin{array}{r}8 \cdot 1-11 \cdot 0 \\
11 \cdot 1-15 \cdot 9 \\
2 \cdot 7-4 \cdot 6 \\
5 \cdot 1-10 \cdot 9\end{array}$ & $\begin{array}{l}14 \cdot 4 \\
14 \cdot 5 \\
10 \cdot 9 \\
11 \cdot 9\end{array}$ & $\begin{array}{r}8 \cdot 5-18 \cdot 6 \\
10 \cdot 7-22 \cdot 9 \\
10 \cdot 0-13 \cdot 0 \\
7 \cdot 2-17 \cdot 0\end{array}$ & $\begin{array}{l}18 \cdot 25 \\
13 \cdot 85 \\
11 \cdot 35 \\
10 \cdot 75\end{array}$ & $\begin{array}{r}8 \cdot 7-24 \cdot 1 \\
11 \cdot 1-18 \cdot 8 \\
9 \cdot 4-12 \cdot 4 \\
7 \cdot 3-12 \cdot 0\end{array}$ \\
\hline
\end{tabular}

longed infusions at 10 and $80 \mu \mathrm{g} \mathrm{kg}^{-1} \mathrm{~h}^{-1}$.

The Wilcoxon rank sum test was used for analysis of the data, which did not follow a normal distribution.

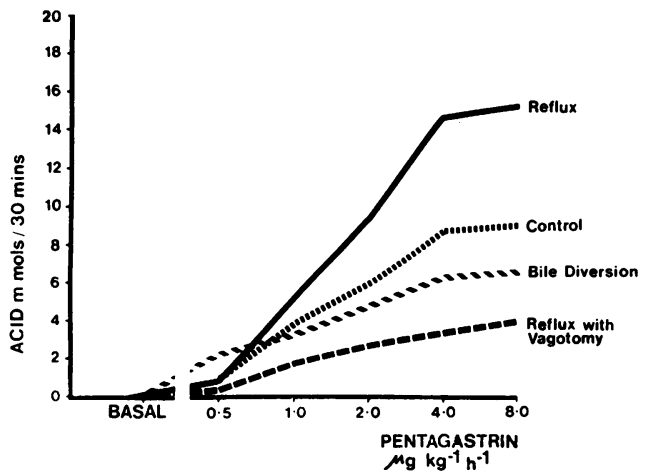

Fig. 2 Median dose response curves to pentagastrin.

\section{Results}

In all the groups the basal acid output was virtually nil. The dose response curves to pentagastrin of the individual groups differed markedly, particularly at the high doses (Fig. 2). In the duodenal reflux group the median response to $8.0 \mathrm{\mu g} \mathrm{kg}^{-1} \mathrm{~h}^{-1}$ showed an increase of $68 \%$ over the control group $(P<0.01)$ with an increase in the gradient of the curve, but no shift of the curve to the left or the right. The responses to 2.0 and $4.0 \mu \mathrm{g} \mathrm{kg}^{-1} \mathrm{~h}^{-1}$ were also significantly larger than the control response $(P<0.05$ and 0.01 respectively), but responses to 0.5 and 1.0 $\mu \mathrm{g} \mathrm{kg}^{-1} \mathrm{~h}^{-1}$ showed no significant difference from controls.

In animals with bile alone diverted into the stomach, the dose response curve closely followed the control curve, although slightly depressed. When all the responses to $8.0 \mu \mathrm{g} \mathrm{kg}^{-1} \mathrm{~h}^{-1}$ pentagastrin are considered in this study, the responses were significantly lower than those produced in control dogs 
$(P<0.01)$. However, the hypersecretion seen in the reflux group was abolished by truncal vagotomy, significantly reducing the responses to all doses, indeed reducing the median maximal response to $8.0 \mu \mathrm{g} \mathrm{kg}^{-1} \mathrm{~h}^{-1}$ by $74 \% \quad(\mathrm{P}<0.01)$.

The reliability and reproducibility of these dose response curves were confirmed by the results of the two subsequent tests using a submaximal dose rate of $1.0 \mu \mathrm{g} \mathrm{kg}^{-1} \mathrm{~h}^{-1}$ and a maximal dose rate of 8.0 $\mu \mathrm{g} \mathrm{kg}^{-1} \mathrm{~h}^{-1}$ of pentagagastrin. In all four groups the responses to both these separate doses showed no significant difference from the responses produced to the same dose concentrations when part of a stepwise dose response curve, thus supporting the work of others. ${ }^{6}$

In the histamine study the dose response curves again differed markedly between the groups, both in the values of the responses and in the shape of the dose response curves (Fig. 3). The reliability and reproducibility of these curves were again confirmed by the results of the two subsequent tests on each dog using a submaximal dose rate of $10 \mu \mathrm{g} \mathrm{kg}^{-1} \mathrm{~h}^{-1}$ and a maximal dose rate of $80 \mu \mathrm{g} \mathrm{kg}^{-1} \mathrm{~h}^{-1}$ of histamine.

The maximal response to histamine occurred in all groups to a stimulus of $80 \mu \mathrm{g} \mathrm{kg}^{-1} \mathrm{~h}^{-1}$ and, on increasing the stimulus to $160 \mu \mathrm{g} \mathrm{kg}^{-1} \mathrm{~h}^{-1}$, the response fell and many of the dogs became restless and started to retch. From the dose response curves, maximal responses showed no significant difference between all four groups, except that when all responses to $80 \mu \mathrm{g} \mathrm{kg}^{-1} \mathrm{~h}^{-1}$ were considered, including the stepwise dose response, and the subsequent separate tests at that dose, then truncal vagotomy reduced the median response in the reflux group by $24 \%(\mathrm{P}<0.01)$, and the bile diversion group again produced less acid than the controls $(P<0.02)$.

On comparing all the maximal responses to histamine with those produced by pentagastrin, it can be seen that there is no significant difference between these responses in the reflux dogs (Fig. 4). However, in the control group the maximal response to histamine is larger than the maximal response to

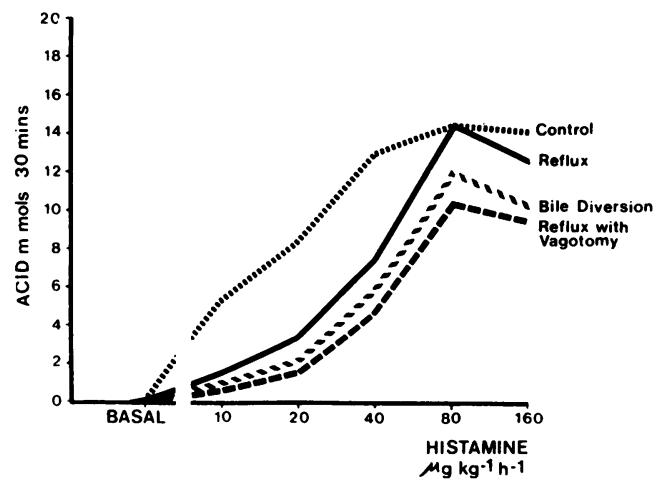

Fig. 3 Median dose response curves to histamine.

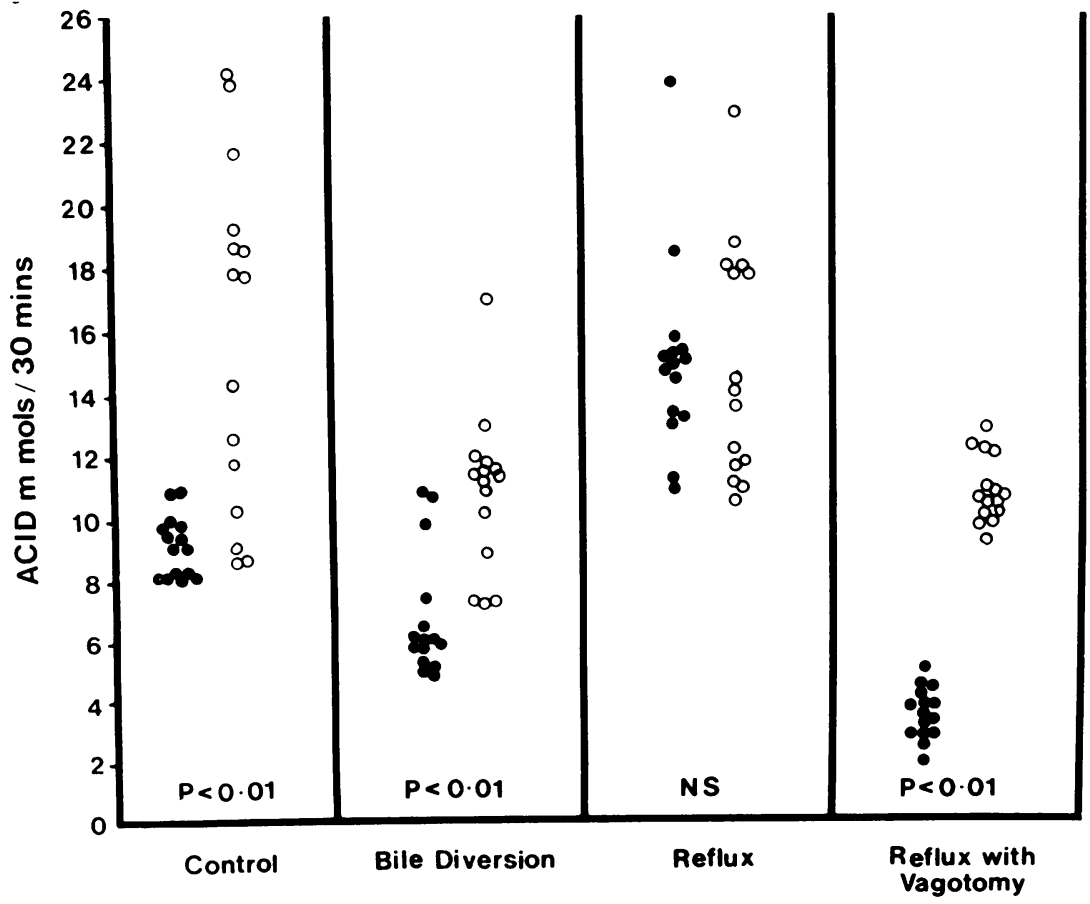

Fig. 4 Comparison of maximal responses to pentagastrin $8.0 \mu \mathrm{g} \mathrm{kg}^{-1} \mathrm{~h}^{-1}$ and histamine $80 \mathrm{\mu g} \mathrm{kg}^{-1} \mathrm{~h}^{-1}$. NS: not significant. 
pentagastrin $(\mathrm{P}<0.01)$ and this is also true for the bile diversion group $(\mathrm{P}<0.01)$ and those with reflux and truncal vagotomy $(P<0.01)$. One must realise the limitations of this analysis as one is not comparing 'like' stimuli, but this is purely an anlysis of maximal response to these simuli.

\section{Discussion}

The results show that dogs with surgically produced duodenal reflux hypersecrete gastric acid to a stimulus of pentagastrin, but not with histamine. This hypersecretion with pentagastrin appears to depend on the pancreatic component of the duodenal contents, because it does not occur with bile diversion.

The difference in response to pentagastrin and histamine may be of importance and the cause is not immediately apparent. Robbins $\mathrm{et} \mathrm{al.}{ }^{7}$ had previously shown a mixed response to Histolog in dogs with a similar procedure, in that three dogs demonstrated a rise in maximal acid secretory capacity, one was unchanged and two showed a fall. They concluded that a trophic effect on the parietal cells, brought about by the exposure of the antrum to duodenal contents, would explain the slight increase in response to Histolog in three of their dogs. However, in this present trial no increase in response to histamine was demonstrated in duodenal reflux and there was no change over a six-month period, suggesting that a trophic effect could not explain the increased secretion with pentagastrin.

Reflux of duodenal contents has been known to cause increased basal acid secretion for many years. Workers investigating the high rate of stomal ulceration after gastrojejunostomy alone have shown an increased acid output from Heidenhain pouches, ${ }^{89}$ which can be reversed by closing the stoma, ${ }^{10}$ or vagal denervation. ${ }^{11}$ This increased basal secretion with duodenal reflux most likely represents increased antral release of gastrin due to the alkaline stimulus, and, if prolonged, may indeed lead to a trophic effect on the parietal cells, causing a further increase in acid response. However, this trial has demonstrated that duodenal reflux acts in a third way to produce an increased acid response and this hypersecretion may be of great importance in the clinical situation.

This hypersecretion did not occur when bile alone was instilled into the stomach via the cholecystogastrostomy. This finding is of interest as well, as Sokolov had shown in $1904^{12}$ that bile instilled into the canine stomach evoked acid secretion from a Pavlov pouch, and others have also confirmed the secretagogue activity of bile. ${ }^{13-15}$ In the present trial ${ }^{\circ}$ however, no increased acid secretion was demon- strated with bile diversion; indeed, the responses in this group were less than controls for both pentagastrin and histamine stimulation. This confirms other workers' results, ${ }^{16}$ that bile will decrease acid secretion in both the basal and stimulated state, and these differences in responses need to be examined. In the experiments where bile appears to act as a secretagogue, it is important to note that there was a large element of stasis. Menguy and $\mathrm{Max}^{17}$ attempted to eliminate this element of stasis by draining the gall bladder through an excluded antrum and found no change in Heidenhain pouch secretion. This finding was supported by Wickbom et al. ${ }^{18}$ who assessed Heidenhain pouch excretion before and after cholecystogastrostomy and found no alteration in acid production. These results indicate that bile alone may not actively stimulate gastrin release unless there is an element of antral stasis.

However, in this study when reflux of alkaline pancreatic juice was added to the bile, by total duodenal diversion, a hypersecretory state was produced. This was again supported by the work of Wickbom et al., ${ }^{18}$ who found that a pancreaticogastrostomy produced a significant increase in Heidenhain pouch secretion, while a cholecystogastrostomy did not. Thus, the hypersecretion seen in the reflux dogs with pentagastrin appeared to be definitely related to the pancreatic component of the reflux, suggesting that this may be due to some pancreatic enzyme or fragment, or even the alkaline $\mathrm{pH}$.

This work was performed while the author was a Bernard-Sunley Fellow at the Royal College of Surgeons and was supported by the East Anglian Regional Health Authority. $\mathrm{He}$ is indebted to Professor J H Wyllie and Professor D E M Taylor for their helpful criticism and advice, and to Professor R Y Calne who provided facilities in the Department of Surgery, Addenbrookes Hospital, Cambridge.

\section{References}

${ }^{1}$ Capper WM, Airth GR, Kilby JO. A test for pyloric regurgitation. Lancet 1966; 2: 621-3.

${ }^{2}$ Flint FJ, Grech P. Pyloric regurgitation and gastric ulcer. Gut 1970; 11: 735-7.

${ }^{3}$ Fiddian-Green R, Russell RCG, Hobsley M. Pyloric reflux in duodenal ulceration and its relationship to smoking. (Abstract.) Br J Surg 1973; 60: 321.

${ }^{4}$ Delaney JP, Butler BA, Cheng JWB, Broadie TA, Ritchie WP. Gastritis induced by intestinal juices. Bull Soc Int Chir 1972; 31: 176-82.

${ }^{5}$ Lawson $\mathrm{HH}$. The distribution and early morphology of the chronic gastric mucosal reaction. Br J Surg 1976 63: $585-588$

${ }^{6}$ Hirschowitz BI, Hutchinson G. Step-dose compared to 
separate-dose response gastric secretion with histamine and pentagastrin in dogs-a kinetic analysis. Scand $J$ Gastroenterol 1974; 9: 207-17.

${ }^{7}$ Robbins PL, Broadie TA, Sosin H, Delaney JP. Reflux gastritis. The consequences of intestinal juice in the stomach. Amer J Surg 1976; 131: 23-9.

${ }^{8}$ Kanar EA, Schmitz EJ, Nyhus LM, et al. Effect of high, low and medium gastrojejunostomy to the main stomach on Heidenhain pouch secretion. Am J Physiol 1953; 175: 167-9.

${ }^{9}$ Jones TW, Stevenson JK, Jesseph JE, Nyhus LM, and Harkins HN. The effect upon free hydrocholric acid production of Heidenhain pouches with variation in size and position of a gastrojejunostomy stoma. Am J Surg 1957; 94: 705-9.

${ }^{19}$ Schmitz EJ, Kanar EA, Storer EH, Sauvage LR, Harkins HN. Heidenhain pouch secretory response as affected by gastrojejunostomy to the main stomach. Proc Soc Exp Biol Med 1952; 81 : 170-2.

${ }^{11}$ Beaver MG, Mann FC. The production of peptic ulcer after section of the gastric nerve. Ann Surg 1931; 94: 1116-8.
${ }^{12}$ Sokolov AP. Analysis of the secretory work of the stomach in the dog. (Thesis) St. Petersburg 1904. Cited by Babkin BP, 1950. Secretory mechanism of the digestive glands, 2nd ed. London, Cassell: p. 642.

${ }^{13}$ Kaulbersz J, Bilski R. Effect of intragastric and intravenous bile on gastric secretion. (Polish.) Acta Physiol Pol 1954; 5: 57-70.

${ }^{14}$ Nahrwold DL. Bile as a gastric secretory stimulant. Surgery 1972; 71: 157-160.

${ }^{15}$ Bedi BS, Debas HT, Gillespie G, Gillespie IE. Effect of bile salts on antral gastrin release. Gastroenterology 1971; 60: 256-62.

${ }^{16}$ Elmasri SH, Lewin MR, Clark CG. In vivo effects of bile salts on acid secretion by the rat stomach. Gut 1977; 18: A405-6. (Abstract.)

${ }^{17}$ Menguy R, Max MH. Influence of bile on the canine gastric-antral mucosa. Am J Surg 1970; 119: 177-82.

${ }^{18}$ Wickbom G, Faith M, Woodward ER, Dragstedt LR. The effect of duodenal regurgitation into the canine stomach on gastric secretion. J Surg Res 1973; 14: $497-500$. 